\title{
The Influence of Oil Prices on Islamic Banking Efficiency Scores during the Financial Crisis: Evidence from the MENA Area
}

\author{
Ali Said \\ Bellevue University, United States.
}

\begin{abstract}
The present paper measured the influence of the oil prices on the Islamic banking efficiencies scores during the financial crisis of 2008-2009. The study showed that there is no a direct relationship between the oil prices and the efficiencies scores of Islamic banks in the MENA area. Furthermore, the study demonstrated that Islamic banks in the GCC area showed a higher mean in pure technical efficiency compared to Islamic banks in the North African and other MENA. Islamic banks in other MENA countries and North Africa considered to be technically inefficient. The inefficiencies were due to the underdeveloped banking system and the lack of experiences in those countries to allocate resources between the bank inputs and outputs.
\end{abstract}

Key Words: Islamic banks; DEA; Efficiency; Oil prices; Regression, MENA

JEL classification: G01; G21; G24

\section{Introduction}

Many of the Middle East countries such as Oman, Saudi Arabia, Qatar, UAE, Bahrain, Kuwait, etc. have undergone a considerable increase in the GDP and many of these countries had a dramatically increase per capita which reached the peak in the beginning-mid 1980s in these countries.

Oil revenue considered being the main sources of revenue of the Middle Eastern and North African (MENA) countries and the substantial amounts of oil revenue have supported the economic growth of these countries. However these countries have faced new challenges during the 2008-2009 financial crisis when the oil prices have decreased which have caused these countries to have declines in exports, revenues, and GDP Furthermore these declined lead to decrease the profitability of many corporations and Islamic banking systems in that area.

The current finance crisis of 2008-2009 and decline in the oil prices has affected the Islamic banking profitable performance through oil correlated activities that banking systems were supporting such as lending and business activities leads many governments to interfere and inject capital to reduce the possibility of the failure of the banking system and ensure the bank is sound to support the economic growth for those countries. The paper is ordered as 


\section{Ali Said/International Journal of Finance \& Banking Studies \\ Vol 4, No 3, 2015 ISSN: 2147-4486}

follows. Section 1 Introduction, Section 2 reports literature review Section 3 Research and methodology hypotheses, and Section 4 focuses on methodology and data collection and Section 5 findings and conclusion.

\section{Literature Review}

In generally, many of researchers have researched different variables that influence the efficiency and the growth in the Islamic banking and striving to show the possible reasons behind the growth in Islamic banks during financial troubles. Some of the studies that review the efficiency of the Islamic bank were (Samad and Hassan, 1999; Samad, 2004) showed that Islamic banking was less risk and more liquid than the western banking system. These studies have used the financial ratios to measure the efficiency and liquidity of these banks.

Other studies such as (Mostafa, 2007; Al Shamsi et al., 2009; Said, 2013) studied the efficiency of the Arab banks system. These studies revealed that Institutional size and resources had an influence on their efficiency. These studies used the Data Envelopment Analysis model to measure the effect of these variables on the efficiency. Other studies (Alkassim, 2005; Darrat, Topuz, \& Yousef, 2002) revealed that total equity had a positive relationship to profitability, capitalization, and efficiency.

Some studies measured the bank efficiency behavior by review different factors such as managerial capabilities, overhead costs, bank size, risk assessment capacity, The legal and institutional environment, and investment management (Demirgüç-Kunt and Huizinga, 1999;Dell'Arriccia and Márquez, 2004; Demirgüç-Kunt and others, 2004).

Other studies that examined the oil price movement influence on significantly economic activities in different countries such as (Cologni and Manera, 2009; Cunado and Perez de Garcia, 2005; Gronwald, 2008; Balaz and Londarev, 2006; Kilian and Vigfusson, 2009; Cologni and Manera 2008). Nevertheless, there is only one study that examined the correlation between oil price shock and bank performance in the MENA area. Poghosyan and Hesse, (2009) analyzed the effect of oil price shock on the operation of banks in MENA countries for the period 2000-2011.

The empirical academic literature mainly focused on Islamic banks performance; efficiency compare to the traditional banking system, and financial stability (Cihák and Hesse, 2008). However does not analyze their relationship to the oil price which the major source of revenue to majoring of countries that Islamic banking operates within. Therefore, this paper makes a significant contribution to the literature on bank efficiency. First, as far as we know, no study has clearly reviewed the correlation between the oil prices and bank efficiency.

\section{Research \& Methodology}

The main purpose of the paper is to analysis the effect of the yearly change oil prices on the efficiency scores of Islamic banks in the MENA during the 2008 financial crisis. The first stage of the paper will applying the different non-parametric DEA methods to obtain obtaining efficiency scores of the Islamic banks in the MENA area during the financial crisis. The second stage of the study the researcher uses the yearly oil price changes, and it influences the Islamic banking efficiency during the 2008 financial crisis that can accomplished by using regression analysis.

\section{Guiding Question}

Does the oil price influence overall efficiency, pure technical efficiency and scale efficiency of Islamic banks operating in the MENA region during the financial crisis?

\section{Guiding Hypotheses}

$\mathrm{H}_{0}$ : Oil price has no influence on the overall efficiency, pure technical efficiency and scale efficiency of Islamic banks operating in the MENA region during the financial crisis.

$\mathrm{H}_{1}$ : Oil price has influenced on the overall efficiency, pure technical efficiency and scale efficiency of Islamic banks operating in the MENA region during the financial crisis.

\section{Definition of Variables and Data}

The researcher utilized the intermediation method to analysis efficiency in Islamic banking using the DEA method because Islamic bank is reflecting an equity-based model. The inputs that have been employed in this study were labor 
cost, fixed assets, and total deposits while the output of the study was total loans, liquid assets, and other income. Islamic banks tend to issue reports in the currency of their country of operations. The researchers thus followed Pastor et al., (1997) by converting the Islamic banks' local currencies into U.S. dollars by using the exchange rate on the first date of the study implementation.

All data for the DEA model were collected from the end-of-year balance sheets and income statements for the individual years 2006 to 2009, which are made available on the website of the banks. While the oil price data were collected from West Texas Intermediate (WTI) - Cushing, Oklahoma. While weekly, monthly or quarterly data for oil prices exist in the databases, low occurrence (yearly) data will be utilized in this research because of the availability of the banks' financial statements. The study sample contained 32 banks from the MENA region, which consists of 18 banks operating in GCC Countries, 8 banks operating in North Africa, and 6 banks operating in other MENA Countries.

\section{Data Envelopment Analysis (DEA)}

The researcher has used the DEA method which is considered to be a linear programming method that change several inputs and outputs of each decision-making unit (DMU) or a bank in this case to measure technical, pure technical, and scale efficiencies for individual banks in the MENA region and compare its performance with that of the best perform DMUs selected from its same group of DMUs.

In this study, the researcher employed the CCR method that was created by Charnes et al., (1978) and BCC that was established by Banker et al., (1984) to acquire efficiency measures consistent to the expectations of CRS and VRS, respectively. The efficiency measures that determined by the CCR model are identified as overall technical efficiency (OTE) scores and are confounded by scale efficiencies. The efficiency measures by using the BCC model are recognized as pure technical efficiency (PTE) scores and without of scale efficiency effects. We can have scale efficiency (SE) for each DMU by a ratio of OTE score to PTE score (i.e., SE=OTE/PTE).

Efficiency $=$ weighted sum of outputs / weighted sum of inputs

$$
\begin{gathered}
\max \sum_{k=1}^{s} v_{k} y_{k p} \\
\text { s.t } \sum_{j=1}^{m} u_{j} x_{j p}=1 \\
\sum_{k=1}^{s} v_{k} y_{k i}-\sum_{j=1}^{m} u_{j} x_{j i} \leq 0, \quad \forall i \\
v_{k}, u_{j} \geq 0 \quad \forall k, j
\end{gathered}
$$

Where, yki : amount of output k produced by DMU i, xji : amount of input j utilized by DMU i, uk : weight given to output $\mathrm{k}$ and vj: weight given to input $\mathrm{j}$. The above fractional equation can be converted to a linear program problem as follows.

$$
\min \theta
$$

$$
\begin{aligned}
& \text { s.t } \sum_{i} \lambda_{i} x_{j i} \leq \theta x_{j p} \quad \forall j \\
& \sum_{i} \lambda_{i} y_{k i} \geq y_{k p} \quad \forall k \\
& \sum_{i} \lambda_{i}=1 \\
& \lambda_{i} \geq 0 \quad \forall i \\
& \text { Peer-reviewed Academic Journal published by SSBFNET with respect to copyright holders. }
\end{aligned}
$$


Equation 3 is solved $\mathrm{n}$ times to identify the relative efficiency scores of all DMUs. Each DMU selects input and output weights that maximize its efficiency score thus an efficient frontier is constructed by the combination of efficient units. In general, a DMU is considered to be efficient if it possess a score of 1 , and a score less than 1 implies that it is inefficient. CCR model considers constant returns to scale (CRS) whereas the BCC model considers variable returns to scale (VRS)

The DEA is created with the best production purpose only based on observed data, so statistical examinations for significance of the parameters is not necessary. The researcher utilized the VRS and CRS Models to determine the relative efficiency of its Islamic banks for the period of 2006 to 2009. Separate measures were calculated for each year. The researcher applied the DEA Excel Solver developed by Zhu (2002).

\section{Regression Analysis}

The second stage of this research shows the influence of the oil price movement on the efficiency scores of the Islamic banks in MENA countries. In this stage, the researcher uses the regression analysis to measure the relationship between the oil price and efficiency. Under the regression analysis, the oil prices will be considered an independent variable while the efficiency scores will be the dependent variables.

$\mathrm{Y}=\mathrm{a} \cdot \mathrm{Xb}$

Where $\mathrm{Y}$ is the oil prices while, $\mathrm{X}$ is representing the efficiency scores of the Islamic banking system in the MENA during the financial crisis and $\mathrm{b}$ is estimated by regression.

\section{Empirical Findings}

In this section, the researcher would be discussing the input-oriented efficiency scores obtained from the CCR and BCC model. The purpose of this quantitative research study was to determine the effect of the change of oil prices on the overall technical efficiency, pure technical, and scale efficiency of Islamic banks operating in the MENA region during the financial crisis 2007-2009 and to address the question: Does the oil price influence overall efficiency, pure technical efficiency and scale efficiency of Islamic banks operating in the MENA region during the financial crisis?

The study sample contained 32 banks from the MENA Region, which consists of 18 banks operating in GCC Countries, 8 banks operating in North Africa, and 6 banks operating in other MENA Countries. The efficiency of Islamic banks in MENA area was first examined by applying the DEA approach for each year by using a common frontier while the second stage the researcher using the regression analysis to examine the influence of yearly oil prices on the efficiency scores.

Table 1 and figure 1 reports shows the means of the efficiency scores for the years 2006, 2007, 2008, 2009, 18 banks operating in GCC Countries, 8 banks operating in North Africa, and 6 banks operating in other MENA Countries for all years.

Table 1: Overall Technical Efficiency, Pure Technical Efficiency, and Scale efficiency scores

\begin{tabular}{llll}
\hline Years & Overall Technical Efficiency & Pure Technical Efficiency & Scale Efficiency \\
\hline 2006 & 0.743 & 0.809 & 0.900 \\
2007 & 0.700 & 0.806 & 0.830 \\
2008 & 0.740 & 0.769 & 0.948 \\
2009 & 0.598 & 0.655 & 0.879 \\
\hline
\end{tabular}




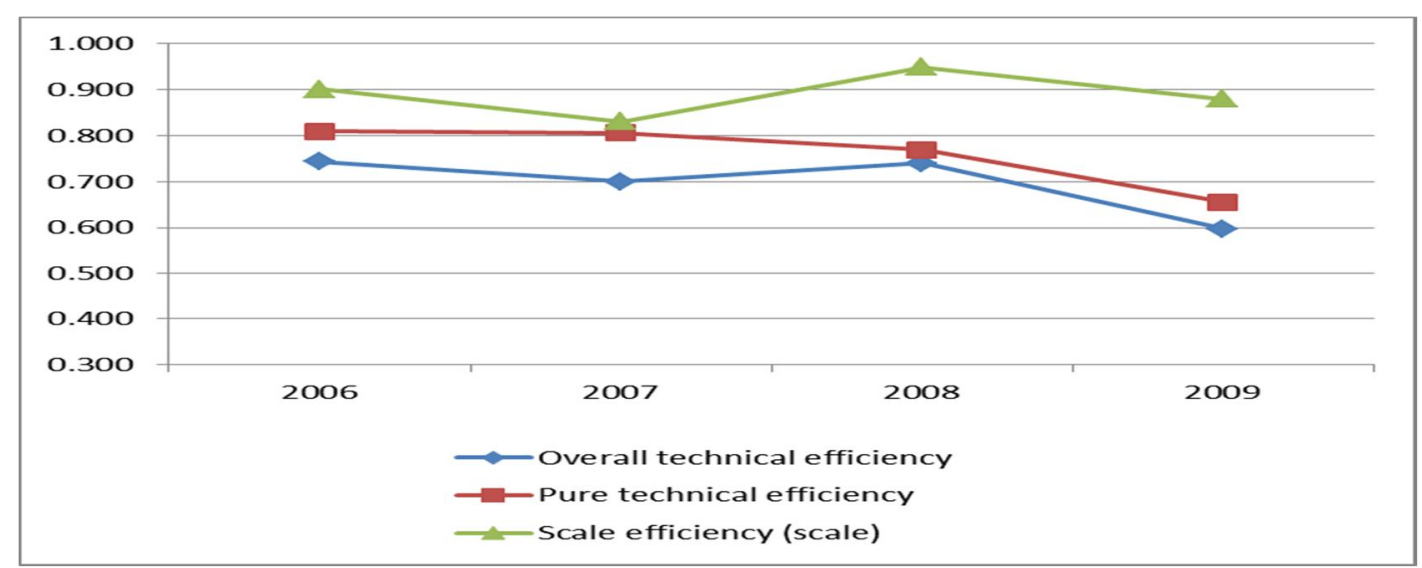

Figure 1. Overall Technical Efficiency, Pure Technical Efficiency, and Scale efficiency scores for all Islamic banks in the GCC, North Africa, and other MENA countries.

Table 1 and figure 1 showed Islamic banks in GCC, North Africa, and other MENA countries overall efficiency scores for each year, that the scale efficiency is greater than pure technical efficiency, and that bank inefficiency was caused by pure rather than scale technical inefficiency.

While table 2 and figure 2 revealed that GCC Islamic banks exhibited a higher mean in pure technical efficiency for each year compared to North African banks and other MENA banks. Which revealed that GCC banks were well managed and more efficient in controlling costs and have been operating at the right scale of operation compared to North African and Other MENA banks. Which this requires that GCC, North African and Other MENA banks could further decrease their elements of production for 2009 by $0.231,0.388,0.633$ respectively, and continuing the same productivity level.

Table 2: Pure Technical Efficiency

\begin{tabular}{llccc}
\hline Banks & 2006 & 2007 & 2008 & 2009 \\
\hline GCC Banks & 0.88 & 0.828 & 0.815 & 0.769 \\
North African Banks & 0.856 & 0.69 & 0.773 & 0.614 \\
Other MENA Banks & 0.535 & 0.894 & 0.627 & 0.367 \\
\hline
\end{tabular}




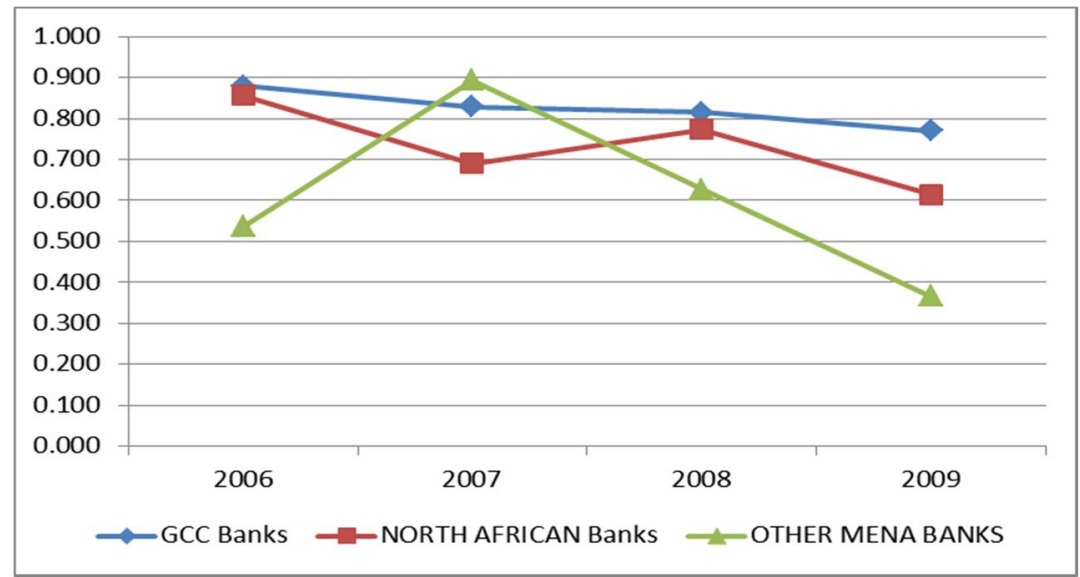

Figure 2. Pure Technical Efficiency

Table 3 and figure 3 showed that GCC banks demonstrated a higher mean in scale efficiency for each year compared to North African banks and other MENA banks.

Table 3: Scale Efficiency

\begin{tabular}{lllll}
\hline Banks & 2006 & 2007 & 2008 & 2009 \\
\hline GCC Banks & 0.956 & 0.861 & 0.976 & 0.934 \\
North African Banks & 0.779 & 0.752 & 0.889 & 0.754 \\
OTHER MENA Banks & 0.895 & 0.841 & 0.946 & 0.883 \\
\hline
\end{tabular}

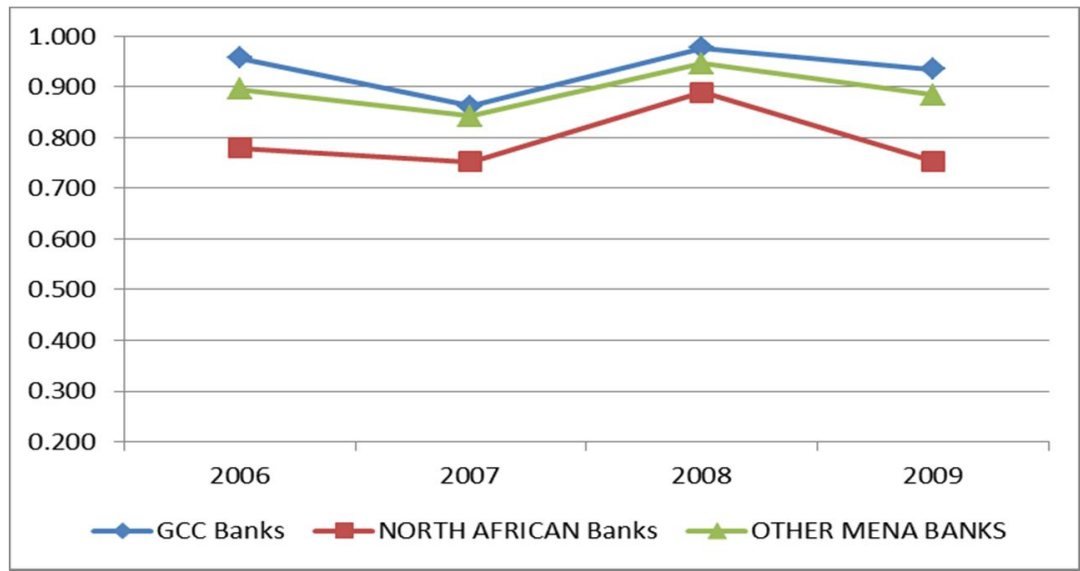

Figure 3. Scale Efficiency

Table 4: Oil Prices

\begin{tabular}{ll}
\hline Year & Average Annual Oil Prices (Dollars Per Barrel) \\
\hline 2006 & 66.05 \\
2007 & 72.34 \\
2008 & 99.67 \\
2009 & 61.95 \\
\hline Source: Crude Oil Prices: West Texas Intermediate (WTI)
\end{tabular}

Source: Crude Oil Prices: West Texas Intermediate (WTI) 


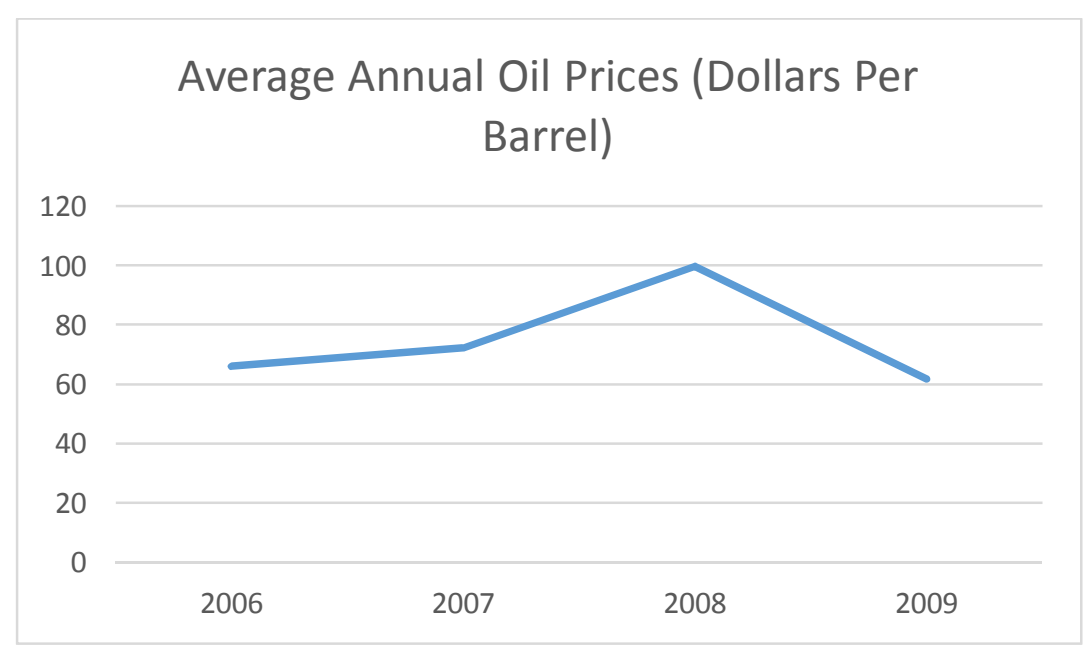

Figure 4: Average Annual Oil Prices

Table 4 and figure 4 showed that oil prices have increased between the periods 2006 to 2008 however the oil prices have decreased for the year of 2009.

Table 5: Overall and Pure Technical Efficiencies

\begin{tabular}{lll}
\hline Efficiencies & R square & P-value \\
\hline Overall Technical Efficiency & 0.31 & 0.85 \\
Pure Technical Efficiency & 0.08 & 0.86 \\
Scale Efficiency & 0.43 & 0.52 \\
\hline
\end{tabular}

P-Value $\leq 0.05$

R-squared value is low between the oil prices and efficiencies scores for the Islamic banks in the MENA Area which can be an indicator of estimate of the strength of the relationship between the price and efficiencies are statistically weak. In addition the P-value were of the overall significance test is above the significance level of .05 and means the alternate hypothesis is weak, so we cannot reject the null hypothesis of oil price has no influence on the efficiencies scores of Islamic banks in the MENA area during the financial crisis.

\section{Conclusions}

The purpose of this study was to measure the influence of the oil prices on the efficiencies scores of the Islamic banks in the MENA area during the financial crisis. The researcher implemented a non-parametric method, namely, the Data Envelopment Analysis to measure the efficiencies scores and regression analysis to measure the relationship between the efficiency scores and oil price. The study results answered the research question and hypotheses:

Does the oil prices influence overall efficiency, pure technical efficiency and scale efficiency of Islamic banks operating in the MENA region during the financial crisis? And hypotheses

H0: Oil prices have no influence on the overall efficiency, pure technical efficiency and scale efficiency of Islamic banks operating in the MENA region during the financial crisis.

H1: Oil prices have influenced on the overall efficiency, pure technical efficiency and scale efficiency of Islamic banks operating in the MENA region during the financial crisis. 


\section{Ali Said/International Journal of Finance \& Banking Studies \\ Vol 4, No 3, 2015 ISSN: 2147-4486}

The results have shown that there is no direct relationship between the oil price and the efficiencies scores of Islamic banks in the MENA area. Also, the P-value were above the significance level that revealed the alternate hypothesis is weak, so we cannot reject the null hypothesis of oil price has no influence on the efficiencies scores of Islamic banks.

Furthermore the study has showed that Islamic banks in the GCC area showed a higher mean in pure technical efficiency compared to Islamic banks in the North African and other MENA area which demonstrated that those banks in GCC area were operating efficiently compare to other banks. Islamic banks in other MENA countries and North Africa considered to be technically inefficient. The inefficiencies were due to the underdeveloped banking system and the lack of experiences in those countries to allocate resources between the bank inputs and outputs. This study considers to first study as we know discusses the efficiency and the prices of oil. Further research should take into consideration other variables that could affect the relationship between the oil prices and banks operations such as size, ownership, and regulation within countries such as GDP, interest rates, and exchange rates.

\section{References}

Alkassim, F. A. (2005). The profitability of Islamic and conventional banking in the GCC countries: A comparative study. Online available at http:// www.failaka.com/downloads/Profitability_Islamic_Banking.pdf

Al Shamsi, F., Aly, H., \& El-Bassiouni, M. (2009). Measuring and explaining the efficiencies of the United Arab Emirates banking system. Applied Economics, 41(27), 3505-3519. doi:10.1080/00036840801964773

Balaz, P. and Londarev, A. (2006), "Oil and its position in the process of globalization of the world economy". Politicka Ekonomie, 54 (4), 508-528.

Banker, R. D., Charnes, A., \& Cooper, W. W. (1984). Some models for estimating technical and scale inefficiencies in data envelopment analysis. Management Science, 30(9), 1078-1092. doi:10.1287/mnsc.30.9.1078

Charnes, A., Cooper, W. W., \& Rhodes, E. (1978). Measuring efficiency of decision making units. European Journal of Operations Research, 6(3), 429-444. Retrieved from http://www.vwl.tuwien.ac.at/hanappi/Lehre/MSM2010/ Charnes_1978.pdf

Cihak, M \& H. Hesse. (2008). Islamic banks and financial stability: An empirical analysis. IMF WP 08/16.

Cologni, A. and Manera, M. (2008). 'Oil Prices, Inflation and Interest Rates in a Structural Cointegrated VAR Model for the G-7 Countries', Energy Economics, 30(3),8569-888.

Cologni, A. and Manera M. (2009), "The Asymmetric Effects of Oil Shocks on Output

Growth: A Markov-Switching Analysis for the G-7 Countries," Economic Modelling, 26, 1- 29.

Cunado, J., Perez de Garcia, F. (2005), "Oil prices, economic activity and inflation: evidence for some Asian countries." The Quarterly Review of Economics and Finance 45 (1), 65-83.

Dell'Ariccia, G. \& R. Marquez, (2004). Information and Bank Credit Allocation. Journal of Financial Economics, 72(1), 185-214.

Demirgüç-Kunt, A. \& H. Huizinga, (1999). Determinants of Commercial Bank Interest Margins and Profitability: Some International Evidence. World Bank Economic Review, 13( 2),379-408.

Demirgüç-Kunt, A., L. Laeven, \& R. Levine, (2004). Regulations, Market Structure, Institutions, and the Cost of Financial Intermediation. Journal of Money, Credit and Banking, 36( 3), 593-622.

Darrat, A.F., Topuz, C. and Yousef, T. (2002). Assessing cost and technical efficiency of banks in Kuwait, Unpublished paper. The ERF 8th Annual Conference, January, Cairo.

Gronwald, M. (2008). "Large oil shocks and the US economy: Infrequent incidents with large effects," Energy Journal, 29, 151-71.

Kilian, L. and R. Vigfusson (2009). Are the Responses of the U.S. Economy Asymmetric in Energy Price Increases and Decreases?. Quantitative Economics, forthcoming. 


\section{Ali Said/International Journal of Finance \& Banking Studies \\ Vol 4, No 3, 2015 ISSN: 2147-4486}

Mostafa, M. (2007). Benchmarking top Arab banks' efficiency through efficient frontier analysis. Industrial Management Data Systems, 107(6), 802. doi:10.1108/02635570710758734

Pastor, J., Pérez, F., \& Quesada, J. (1997). Efficiency analysis in banking firms: An international comparison. European Journal of Operational Research, 98(2), 395-407. doi:10.1016/S0377-2217(96)00355-4.

Poghosyan, T. and Hesse, H. (2009). Oil prices and bank profitability: evidence from major oil-exporting countries in the Middle East and North Africa. Middle East and Central Asia Department, International Monetary Fund Working Paper.

Said, A., (2013). Risks and Efficiency in the Islamic Banking Systems: The Case of Selected Islamic Banks in MENA Region. International Journal of Economics and Financial Issues 3(1), (2013), 66-73.

Samad, A., \& Hassan, M.K. (1999). The performance of [the] Malaysian Islamic bank during 1984-1997: An exploratory study. International Journal of Islamic Financial Services, 4(1), 55-69.

Samad, A. S. (2004). Performance of interest free Islamic Banks vis-à-vis interest-based conventional banks of Bahrain. IIUM Journal of Economics and Management, 12(2), 1-15. Retrieved from http://www.iiu.edu.my/enmjournal/ 122art1.pdf

Zhu, J. (2002), "Quantitative Models for Performance Evaluation and Benchmarking: Data Envelopment Analysis with Spreadsheets and DEA Excel Solver", Norwell, MA: Kluwer Academic Publishers Group. 